Ann. Biol. anim. Bioch. Biophys., 1979, 19 (3 A), 637-646.

\title{
LH and testosterone responses to gonadoliberin (LRH) treatment in young bulls prior to and during puberty
}

par P. CHANTARAPRATEEP (1), M. THIBIER ( ${ }^{(2)}$

Laboratoire d'Hormonologie, U.N.C.E.I.A., 13, rue Jouet, 94700 Maisons-Alfort, and Institut National Agronomique Paris-Grignon, France.

Summary. The LH and testosterone release affer a single injection $(0.25 \mathrm{mg})$ of Gonadoliberin (LRH) were studied in a total of 23 bulls before and about puberty. Both LH and testosterone were measured by radioimmunoassay of jugular vein blood samples taken at frequent intervals.

LRH caused release of $\mathrm{LH}$ at all ages but the magnitude of the $\mathrm{LH}$ increase in response to LRH was significantly higher at 3 and 5 months (mean total response $4.3 \mu \mathrm{g} / \mathrm{ml} \times 150 \mathrm{~min}$ ) than at older ages $(3.1 \mu \mathrm{g} / \mathrm{ml} \times 150 \mathrm{~min}$.). By contrast the mean total response of testosterone to LRH increases from very low levels $(0.07 \mu \mathrm{g} / \mathrm{ml} \times 150 \mathrm{~min})$ at 3 months of age to about $0.65 \mu \mathrm{g} / \mathrm{ml} \times 150 \mathrm{~min}$. between the ages of 7 and 13 months.

The mean LH responses vary significantly among individuals and the intra-class correlation coefficient $r$ is 0.3 ( $p<0.02$ ).

These results provide evidence of two distinct periods prior to puberty with regard to $\mathrm{LH}$ and testosterone release in response to LRH : one before 7 months of age during which $\mathrm{LH}$ release is very sensitive to LRH and the testosterone low, and the other from 7 months until after puberty, when no more changes in the magnitude of the responses can be seen. However, the individual magnitude of the response during the second period does not seem to be independent of that seen in the former period.

\section{Introduction.}

A further understanding of pituitary - testes relationships in the young bull might be achieved by critical determination of pituitary gonadotropic and gonadal hormone concentrations at various ages prior to or around the time of puberty. Puberty, defined as the release of the first spermatozoa, occurs in this species at about the eigth or ninth month after birth (Ortavant et al., 1977).

The reprints should be requested to : Laboratoire d'Hormonologie, UNCEIA, 13, rue Jovet, 94700 Maisons-Alfort, France.

(1) Present address : Faculty of Veterinary Science, Chulalongkorn University, Henry Dunant Street, Bangkok, 5, Thailand.

(2) Present address : Endocrine Laboratory, School of Medicine, University of Miami, P. O. Box 016960 Miami Fla 33101, USA. 
The magnitude and time course of increased plasma luteinizing hormone (LH) and testosterone after gonadoliberin (LRH) administration have already been reported in bulls after puberty (Thibier, 1976b, 1977). Both a between-individuals variability, as seen in some other species (Schally ef al., 1972 ; Hopkinson ef al., 1974) as well as a within-animal « repeatability » over a short period of time interval was observed. LH and testosterone concentrations have also been shown to increase in prepubertal bulls after LRH injection (Mongkonpunya ef al., 1975 ; Lacroix, 1976 ; Tannen and Convey, 1977 and Kesler and Garverick 1977). However some discrepancies may be found in the mean variation of the total response of both hormones to such treatment (Mongkonpunya ef al., 1975 ; Lacroix, 1976 ; Kesler and Garverick, 1977). Finally because of too few bulls per age or an insufficient number of periods studied, the withinindividuals correlation of their responses with advancing ages has not yet been investigated.

The aim of the present study, therefore was to determine endocrine changes, associated with pubertal maturation of bulls, by an injection of LRH. In addition we wished to test the so-called « repeatability » of the LH and testosterone responses to a gonadotropin releasing hormone treatment in bulls kept under similar conditions from the first month of life until after puberty (11-13 months).

\section{Material and methods.}

This study involved 23 «Pie Rouge de l'Est » bulls aged from 3 to 13 months old. They were introduced and kept under identical management conditions at the performance test station (Umotest, 01250 Ceyzeriat) since they were about 2 weeks old. At 10 months of age, they were submitted to semen collection weekly ( 2 ejaculations) by arfificial vagina. They all displayed normal libido, and from 15 semen collections (between 47 and 65 weeks old) the mean characteristics for the first and the second ejaculations were respectively : volume 2.50 and $2.90 \mathrm{ml}$, sperm concentration $\left(\times 10^{9}\right)$ 1.08 and 0.87 , of which 64 p. 100 and 60 p. 100 were found to be motile.

The injections of LRH were performed every other months over one year and was designed so that at the end of the experiment, there were 12 bulls for each age group. Each bull was injected intra-muscularly with a single dose $(0.25 \mathrm{mg})$ of a synthetic gonadoliberin LRH (Intervet, 49005 Angers, France) in the morning (8.00 a. m.). Six bulls were simultaneously submitted to the test on each occasion and five of them went through the experiment at all ages studied from 3 to 13 months old.

After a first sample prior to LRH injection, blood was taken every $15 \mathrm{~min}$. for $21 / 2 \mathrm{hrs}$ and thereafter every 1 hour for another four hours. All blood samples were collected by jugular venepuncture into heparinized evacuated tubes. They were centrifuged at $3000 \mathrm{~g}$ for $10 \mathrm{~min}$., and plasma was removed and stored at $-20^{\circ} \mathrm{C}$ until required for assayed. LH was measured in all plasma samples from the same occasion, by radioimmunoassay, as previously described (Thibier, 1975a). Details of the radioimmunoassay of testosterone have also been reported previously (Thibier 1976a). For an estimate of the amount of LH or testosterone released, a so-called "total response » has been used and as described previously (Thibier 1976b) calculated from the area under the curve during $150 \mathrm{~min}$. This response is expressed as $\mu \mathrm{g} / \mathrm{ml} \times 150 \mathrm{~min}$. 
The results are given in terms of mean \pm SD and evaluated by Student's $t$ test. The "repeatability » was estimated by calculation of the intra-class coefficient of correlation according to Snedecor and Cochran (1956).

\section{Results.}

Preinjection concentrations of plasma $\mathrm{LH}$ and testosterone.

As illustrated in table 1, LH and testosterone concentrations before LRH injection show significant variations according to age. The $\mathrm{LH}$ concentrations are significantly higher $(p<0.01)$ at 3 and 5 months of age than later. The testosterone mean concentrations significantly increase $(p<0.02)$ from the first age studied to 7 months old. After 7 months, neither LH nor testosterone have significantly different values up to 13 months of age.

TABLE 1

Mean ( \pm SD) of plasma LH and testosterone concentrations $(\mathrm{ng} / \mathrm{ml})$ in 12 bulls for each age group, sampled every other month from the age of 3 to 13

\begin{tabular}{ccc}
\hline Age (months) & LH & Testosterone \\
& & \\
\hline & & \\
3 & $1.14 \pm 0.56\left({ }^{1}\right)$ & $0.22 \pm 0.19\left(^{(2)}\right.$ \\
5 & $1.33 \pm 0.70\left({ }^{1}\right)$ & $1.68 \pm 1.15\left(^{(2)}\right.$ \\
7 & $0.54 \pm 0.48$ & $2.64 \pm 1.65$ \\
9 & $0.79 \pm 0.69$ & $2.72 \pm 2.64$ \\
11 & $0.69 \pm 0.33$ & $2.19 \pm 1.79$ \\
13 & $0.80 \pm 0.66$ & $3.06 \pm 1.67$ \\
& & \\
\hline
\end{tabular}

(1) Significantly higher than at older ages $(p<0.01)$.

(2) Significantly lower than at older ages $(p<0.02)$.

Response of $L H$ to $L R H$ injection.

Mean plasma LH increased 15 -fold within 15 min after LRH injection and declined to preinjection concentrations within $51 / 2 \mathrm{hrs}$ after LRH (fig. 1). The mean maximum increase in plasma LH after LRH was higher at 3 and 5 months (about $35 \mathrm{ng} / \mathrm{ml}$ ) and was reached within 45 to 60 min., whereas at older ages it was less than $30 \mathrm{ng} / \mathrm{ml}$ and the maximum was reached within 90 to $120 \mathrm{~min}$.

Mean total LH responses $(\mu \mathrm{g} / \mathrm{ml} \times 150 \mathrm{~min}$.) were between $4.55 \pm 1.47$ (at 5 months old) and $2.76 \pm 0.97$ (at 11 months old). As illustrated in figure 2 they are significantly higher in the first two groups ( 3 and 5 months) than in the others $(p<0.01)$. The highest values within individuals (those $>30 \mathrm{ng} / \mathrm{ml}$ ) were found more frequently between 45 and $60 \mathrm{~min}$. at 3 and 5 months of age, whereas they occurred most of the time by the $90-120 \mathrm{~min}$. in the three oldest groups. The 7 months group was intermediate. 


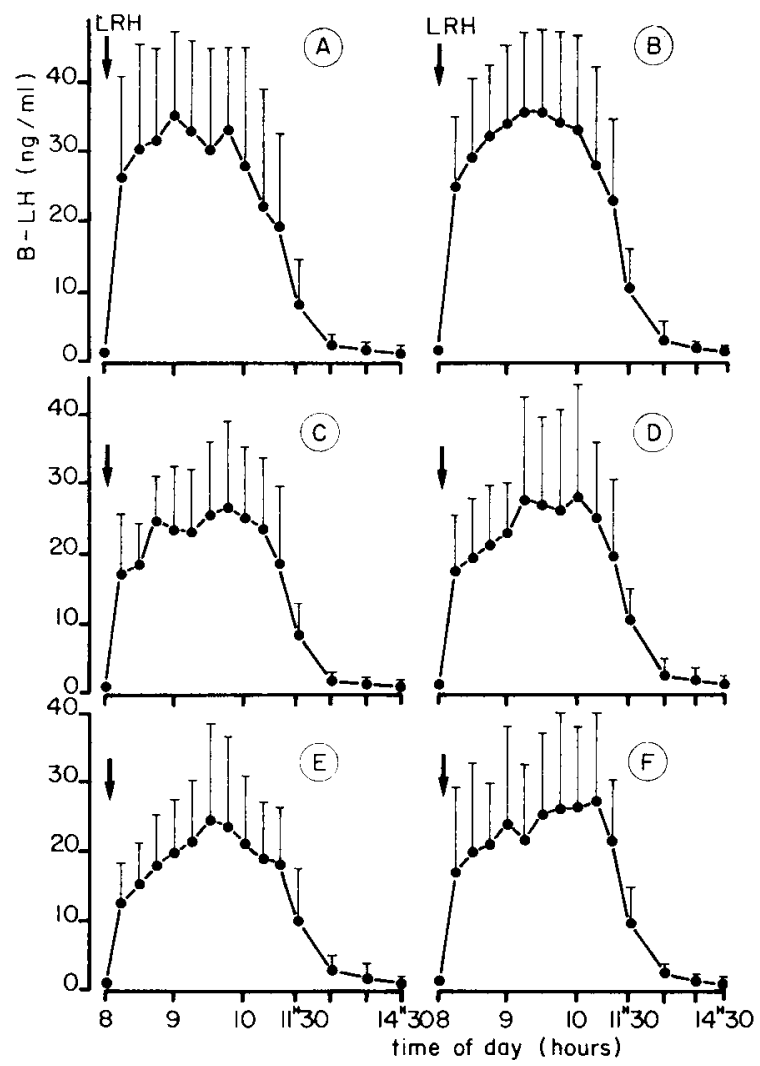

FIG. 1. - Plasma LH concentration following treafment with $0.25 \mathrm{mg}$ gonadoliberin (LRH, arrow). Each point represents the mean $\pm S D(T)$ of 12 observations. A, B, C, D, E, and $F$ represent the age group of bulls at $3,5,7,9,11$ and 13 months, respectively.

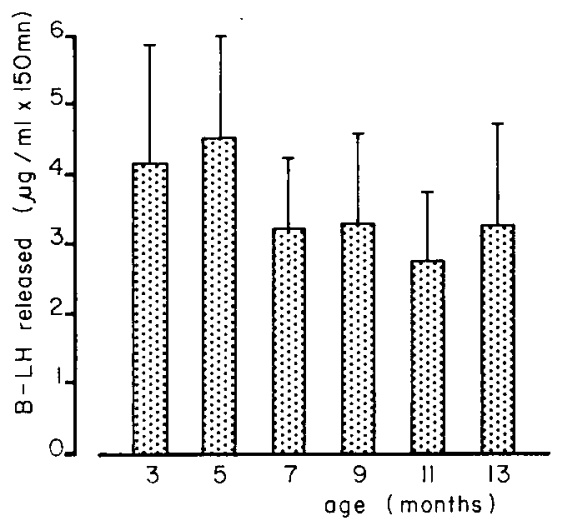

FIG. 2. - Mean total response $\pm \mathrm{SD}(\mathrm{T})$ of 12 observations of plasma LH following treatment with $0.25 \mathrm{mg}$ gonadoliberin according to age. 
Response of testosterone to $L R H$ injection.

The magnitude of the increase of plasma testosterone concentration was about 2 fold following LRH injection in all group except the 3 months old bulls (fig. 3 ). The decline to preinjection levels was observed within $61 / 2 \mathrm{hrs}$. As shown in figure 4 the mean total response $(\mu \mathrm{g} / \mathrm{ml} \times 150 \mathrm{~min})$ is low at 3 months of age $(0.07 \pm 0.05)$, then

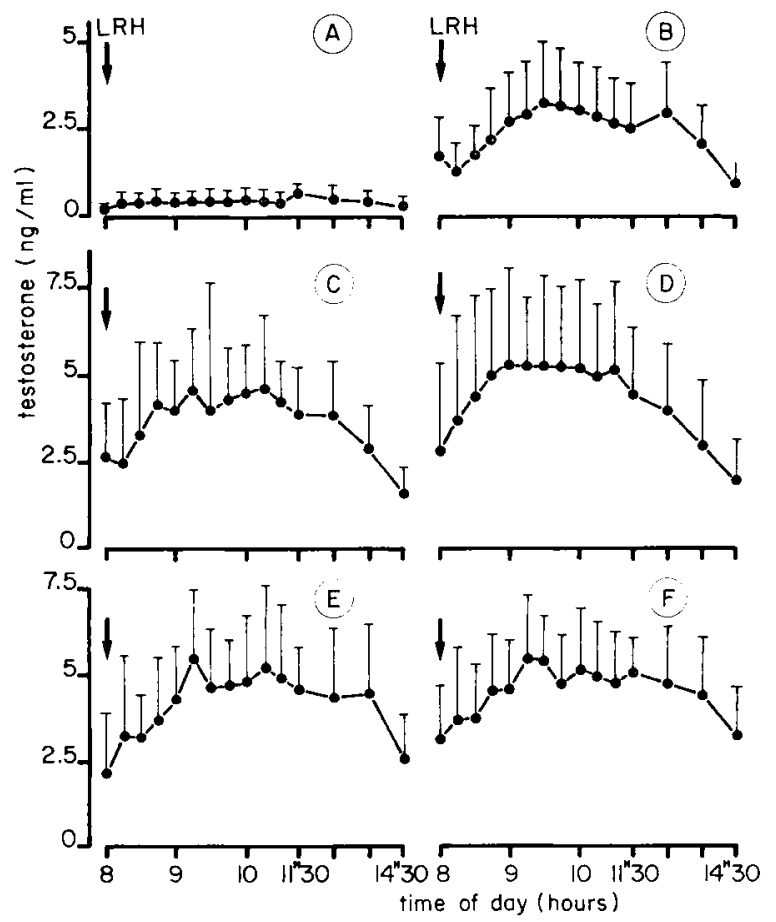

FIG. 3. - Plasma testosterone concentrations following treatment with $0.25 \mathrm{mg}$ gonadoliberin (LRH, arrow). Each point represents the mean $\pm S D(T)$ of 12 observations. A, B, C, D, E and $F$ represent the agelgroup of bulls at $3,5,7,9,11$ and 13 months respectively.

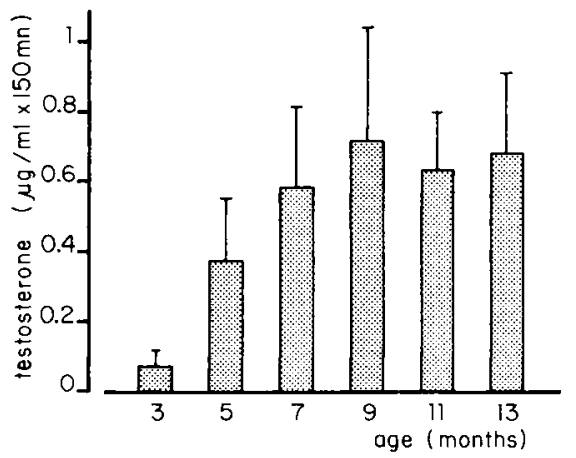

FIG. 4. - Mean total response $\pm S D(T)$ of 12 observations of plasma testosterone following treatment with $0.25 \mathrm{mg}$ gonadoliberin according to age. 
increases significantly at the following two ages studied and remains at about $0.65 \mu \mathrm{g} /$ $\mathrm{ml} \times 150 \mathrm{~min}$. from 7 to 13 months of age. There was no particular hour after injection at which high levels within individuals were observed.

Intra-class correlation of $\mathrm{LH}$ and testosterone responses.

The large coefficient of variation of the mean $L H$ response (30 to 45 p. 100) shows evidence of a large variability among individuals. From the 5 bulls which were subjected to the test at all ages, the coefficient of repeatability was $r=0.30(p<0.02$ ). Furthermore, when taking into account those submitted to LRH injection on 4 consecutive occasions ( 7 to 13 months; $n=8$ ) or else on 3 occasions ( 9 to 13 months ; $n=10$ ), it was found that the coefficient of repeatability was similar to that of the 5 bulls, i. e. about 0.3. Figure 5 illustrates this repeatability. For example the response of bull no. 848 remained above the mean value at each age groups.
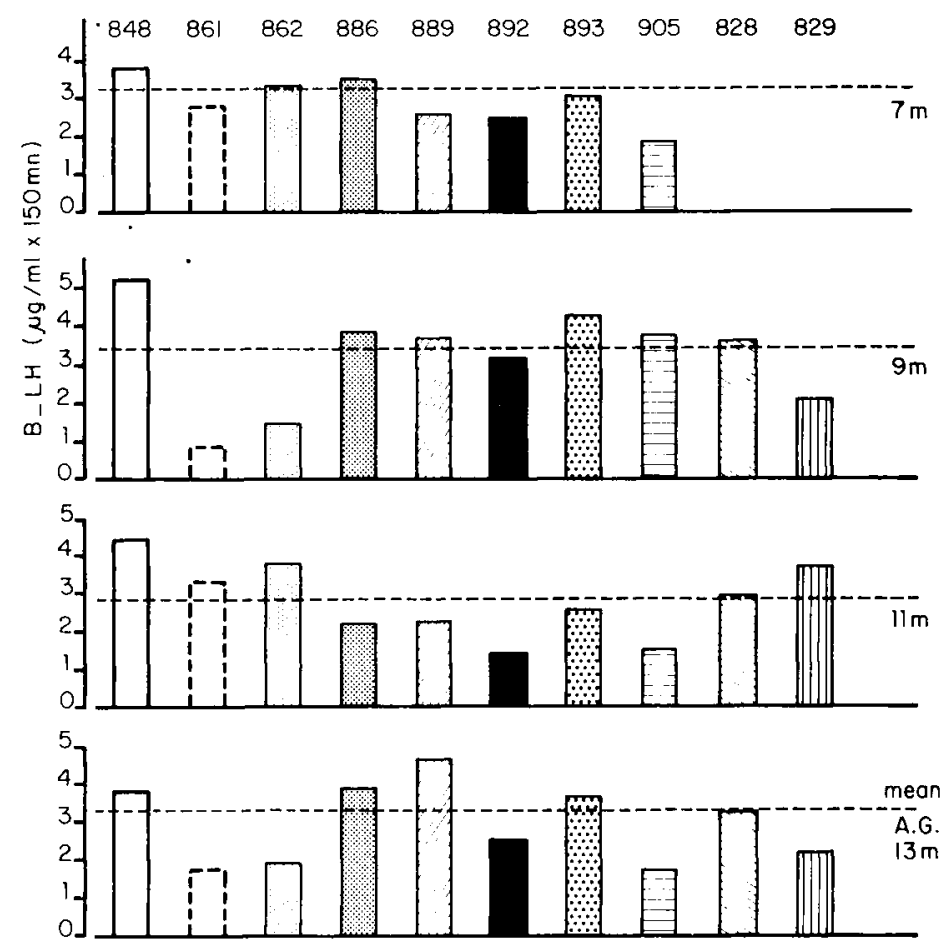

FIG. 5. - Repeotability of the total response of $\mathrm{LH}$ following treatment with $0.25 \mathrm{mg}$ gonadoliberin in $7,9,11$ and 13 months old bulls. $(\mathrm{m}=$ month ; A. G. = age group ; dotted lines represent mean total reponse of each age group).

By contrast, no significant coefficient of intra-class correlation was calculated from the testosterone data, indicating that there was no repeatability of the withinbulls response of testosterone to LRH during the growth period from 3 to 13 months of age.

Finally, it was found that there were no significant correlations between the total responses of $\mathrm{LH}$ and those of testosterone at each age group. 


\section{Discussion.}

The results of this study show evidence : 1) of different $\mathrm{LH}$ and testosterone responses to $L R H$ injection according to age and 2) of a significant intraclass correlation in the $L H$ responses to the $L R H$ administration.

Both LH and testosterone mean concentrations prior to LRH injection show significant variations according to age. The number of animals per group $(n=12)$ was relatively small and therefore mean values might have been influenced to some extent by quick pulses of both hormones (Thibier, 1975b, 1976a), but nevertheless these results are in total agreement with independent previous studies either from numerous animals per age group (Thibier, 1977) or from a few bulls submitted to regular blood sampling (Lacroix et al., 1977). It is therefore seen that in untreated bulls, mean plasma $\mathrm{LH}$ levels are higher prior to 7 months of age than after, whereas those of testosterone do increase until 7 months of age. The LH and testosterone responses to LRH followed the same pattern with increasing age, when determined in these same bulls. It has been shown previously that $\mathrm{LRH}$ was indeed able to induce an increase in the LH plasma concentration in prepubertal bulls (Mongkonpunya et al., 1975) and even as early as in one day old calves (Kesler and Garverick, 1977), as well as in lambs (Lee et al., 1976). Here we observe that the mean magnitude of this response to LRH appears to be age dependent and significantly higher before 7 months of age than after. This confirms primarily that the hypophysis is very sensitive to LRH at early ages and much before puberty. Even more interesting is the fact that this sensitivity appears to decrease at least 2 to 3 months before puberty. Parlow ef al. (1964) reported that the quantities of stored pituitary LH in the pigs were at least twice as high in prepubertal than in postpubertal males, which is consistent with the present findings. Similarly, McMillan and Hafs (1968) and later Purchas et al., (1970) observed a regular increase of the weight of the hypophysis during the first months of life in calves. In lamb, Foster (1974) and Courot et al. (1975) also found an increased activity of the hypophysis before puberly compared to after.

It is possible that the use of a single dose of $L R H$ in growing animals contributed to the observed variation in response with age. Various factors for adjusting the dose to the individual animal e. g. by weight or age, were considered and rejected as too approximate or inappropriate for these experiments. It seems unlikely that the single dose used was solely responsible for the changes observed, since Mongkonpunya ef al. (1975) reported that the variation of the dose injected (from 0.2 to $0.8 \mathrm{mg}$ ) was with no influence on the magnitude of the mean response in young bulls aged between 2 and 6 months of age.

It can also be seen that apart from modulating the magnitude of the $\mathrm{LH}$ response, age also modified the time course of that response. Although the concentration of $\mathrm{LH}$ was elevated about 15 times above the preinjection concentrations in all age groups, in accordance with previous reports (Mongkonpunya ef al., 1975 ; Lacroix ef al., 1977 ; Thibier, 1976, 1977) this elevation seems more rapid in the young animals than in the older ones. The maximal plasma levels were on the whole reached 45 to $60 \mathrm{~min}$. after the injection took place for the first two age groups, therefore at least half an hour earlier than in older groups ( 90 to $120 \mathrm{~min}$.). The return to preinjection levels did not 
seem to vary according to age groups and was similar to that reported from animals of various ages by Mongkonpunya ef al. (1975) and Thibier (1976b).

Both the higher magnitude of the $\mathrm{LH}$ response and the shorter latency from the LRH injection, therefore, occur in the first 7-8 months of age. Steroids and particularly androgens, have been widely reported to be able to regulate and reduce the $\mathrm{LH}$ response to LRH by various mechanisms (Schally ef al., 1972 ; Galloway and Pelletier, 1975 ; Labrie et al., 1977). And indeed from previous studes quoted above as well as from this study, it was shown that in untreated animals mean testosterone concentrations do increase in the young up to 7 months of age and then plateau. In the present study, the testosterone response to LRH follows this same pattern : very small response at 3 months, increased at 5 months and then higher and with no further increment at 7, 9, 11, and 13 months, i. e. before and during puberty. The lack of a high response at the youngest age studied here is consistent with the previous report by Hooker (1970) who observed that the differentiation of mesenchymal or fibroblastic cells of the testicular interstitium in bull calves began at about $31 / 2$ months and they developed into competent secretory cells during the following $31 / 2$ months. The magnitude of the total testosterone response in the 7 to 13 months old bulls is also in good agreement with earlier findings by Thibier $(1976 \mathrm{~b}, 1977)$ and Lacroix ef al. (1977).

The variations in both $\mathrm{LH}$ and testosterone responses to LRH before or during puberty provide therefore, a further insight into the prepubertal development of the $\mathrm{LH}$-testosterone relationship. Definitely the LH release is very sensitive to LRH at the younger ages and as the interstitial cells increase their secretory activity (as shown by the testosterone concentrations increment as well as by their ability to respond to elevated LH levels) the pituitary sensitivity seems to decrease. These findings give support to an early "key period » before puberty, occurring around 7 months of age, at which time the balance in the pituitary-testis interaction is reached. Because of this time occurrence, it is tempting to speculate that such a balance should be reached and required before the onset of spermatogenesis.

The second major feature of this study was both the large variations among individuals at a specific age (coefficient of variation : 30 to 50 p. 100) and the repeatability within-animals of the LH response to LRH. It has been reported before in rats (Schally ef al., 1972), in rams (Hopkinson ef al., 1974) and in bulls (Thibier 1976b) that there were large individual variations. Only in the latter study has the repeatability of such a response been investigated. It was, however, in a short period of time (one month apart) and after puberty. In the present study, the intra-class coefficient of correlation was found to be significant but not very high (0.3). Although the number of animals $(n=5)$ submitted to the test at all the 6 ages was small, this figure was found again when more bulls with 3 or 4 tests each were taken into account. This leads us to two considerations. First, the magnitude of the coefficient shows that all the variation is not due to environmental conditions. A part of it (about 30 p. 100) is related to the individual genotype. The majority of the variation, however, is dependent upon the environmental factors. The second point is that the repeatability is seen before and at puberty but also prior to and after the 7 months « key period ». This means that although mean responses to LRH vary with advancing ages, the individual magnitude of the response at 7 months or later is not independent of that occurring before. When 
contemporary comparisons are being made, those with the higher responses at the earliest ages, for instance, tend to keep those high responses later and vice versa.

In conclusion, a balance between mean responses of $\mathrm{LH}$ and testosterone to LRH seems to be reached at about 7 months of age and therefore before the onset of spermatogenesis. In addition, within individuals $L H$ responses to $L R H$ were found to be « repeatable » suggesting a significant genotypic influence.

Reçu en septembre 1978.

Accepté en décembre 1978.

Acknowledgments. - The authors wish to thank Mrs N. Jeanguyot for her skilfull technical assistance, Messrs F. Mercier and G. Abdel Malak B. for helpful collections of blood samples. The LRH generously donated by Dr A. Constantin (Intervet, 49005 Angers) is also acknowledged. We appreciated the help of Dr M. R. Clark for the correction and suggestions in the English manuscript.

Résumé. La réponse de $\mathrm{LH}$ et de testostérone plasmatiques au test de la stimulation par la gonadoliberine LRH a été étudiée à partir de 23 taurillons à 6 âges-types entre 3 et 13 mois.

Les deux hormones ont été dosées par la méthode raioimmunologique. Aux deux premiers âges types, la réponse hypophysaire de LH après ce traitement est supérieure $(p<0,01)$ a celles observées aux âges ultérieurs (valeurs moyennes : 4,30 $\mu \mathrm{g} / \mathrm{ml} \times 150 \mathrm{~min}$ vs $3,1 \mu \mathrm{g} / \mathrm{ml} \times 150 \mathrm{~min}$ ). La réponse de LH à ce test est variable entre individus et répétable pour un même animal $(r=0,3 ; p<0,02)$.

Ces résultats montrent qu'il y a deux périodes dans l'évolution de l'activité hypophysaire de la première année de vie, d'une part entre 3 et 5 mois et d'autre part après 5 mois. La réponse individuelle de $\mathrm{LH}$ à la deuxième période ne semble toutefois pas indépendante de celle de la première.

\section{References}

COUROT M., DE REVIERS M. M., PELLETIER J., 1975. Variations in pituitary and blood LH during puberty in the male lamb. Relation to time of birth. Ann. Biol. anim. Bioch. Biophys., 15, 509-516.

FOSTER D. L., 1974. Regulation of gonadotropins during fœtal and early post natal development in the sheep. In Coll. INSERM, 32, 143-156.

GALLOWAY D. B., PELLETIER J., 1975. Luteinizing hormone release in entire and castrated rams following injection of synthetic luteinizing hormone releasing and effect of testosterone propionate treatment. J. Endocr., 64, 7-16.

HOOKER C. W., 1970. The intertubular tissue of the testis, 483-550. In JOHNSON A. D., GOMES W. R., VAN DEMARK N. L., The Testes. Acad. Press, New York, London.

HOPKINSON C. R. N., PANT H. C., FITZPATRICK R. J., 1974. Release of LH and FSH in the normal intact ram by synthetic LH-RF and the effect of pretreatment with testosterone propionate. $J$. Reprod. Fert., 39, 135-139.

KESLER D. J., GARVERICK H. A., 1977. Lutienizing hormone and testosterone concentrations in plamma of bull calves treated with gonadotropin releasing hormone. J. Dairy Sci., 60, 632-634.

LABRIE F., DROUIN J., FERLAND L., DELEAN A., LAGACE L., BORGEAT P., 1977. Mechanism of action of hypothalamic hormones and modulation of their activity, 168-174. In JAMES V. H. T., Endocrinology, vol. 1, Excerpta med., Amsterdam. Proceed. 5th int. Congr. Endocrinol., Hamburg, 1976.

LACROIX A., 1976. Variations de la $\mathrm{LH}$ ef de la testosterone plasmatiques chez le veau mâle entre la naissance ef la puberté ; mise en place du mécanisme de rétroaction. Thèse Doct. $3^{e}$ cycle, Paris, 66 p. 
LACROIX A., GARNIER D. H., PELLETIER J., 1977. Temporal fluctuations of plasma LH and testosterone in Charolais bull calves during the first year of life. Ann. Biol. anim. Bioch. Biophys., 17, 1013-1019.

LEE V. W. K., CUMMING I. A., DE KRETSER D. M., FINDLAY J. K., HUDSON B., KEOGH E. J., 1976. Regulation of gonadotrophin secretion in rams from birth to sexual maturity. I. Plasma, LH, FSH, and testosterone levels J. Reprod. Fert., 46, 1-6.

MCMILLAN K. L., HAFS D. H., 1968. Pituitary and hypothalamic endocrine changes associated with reproductive development of Holstein bulls. J. Anim. Sci., 27, 1614-1620.

MONGKONPUNYA K., HAFS H. D., CONVEY E. M., TUCKER H. A., OXENDER W. D., 1975. Serum luteinizing hormone, testosterone and androstenedione in pubertal and prepubertal bulls after gonadotropin releasing hormone. J. Anim. Sci., 40, 683-686.

ORTAVANT R., COUROT M., HOCHEREAU DE REVIERS M. T., 1977. Spermatogenesis in domestic mammals, 203-227. In COLE H. H., CUPPS P. T., Reproduction in domestic animals. Acad. Press, New York, London,

PARLOW A. F., ANDERSON L. L., MELAMPY R. M., 1964. Pituitary follicle-stimulating hormone and luteinizing hormone concentrations in relations to reproductive stages of the pigs. Endocrinology, 75, 365-376.

PURCHAS R. W., MCMILLAN K. L., HAFS H. D., 1970. Pituitary and plasma GH levels in bulls from birth to one year of age. J. Anim. Sci., 31, 358-363.

SCHALLY A. V., KASTIN A. J., ARIMURA A., 1972. The hypothalamus and reproduction. Am. J. Obs. Gynec., 114, 423-442.

SNEDECOR G. W., COCHRAN W. G., 1956. Statistical methods (5th ed.) 534 pp. lowa State Univ. Press (Aimes, U.S.A.).

TANNEN K. J., CONVEY E. M., 1977. Gonadotropin releasing hormone induced change in serum luteinizing hormone, testosterone and androstenedione in bulls, steers given testosterone. J. Anim. Sci., 44, 1080-1087.

THIBIER M., 1975a. Variations circadiennes de la LH plasmatique chez le jeune taurillon. Ann. Endocr. Paris, 36, 205-210.

THIBIER M. 1975b. Peripheral plasma testosterone concentrations in bulls around puberty. J. Reprod. Fert., 42, 567-569.

THIBIER M., 1976a. Diurnal testosterone and $17 \alpha$-hydroxyprogesterone in peripheral plasma of young post-pubertal bulls. A study by frequent sampling. Acta endocr., 81, 623-634.

THIBIER M., 1976b. Effect of synthetic gonadotropin releasing hormone $(\mathrm{Gn}-\mathrm{RH})$ on circulating luteinizing hormone (LH) and testosterone in young post-pubertal bulls. Acta endocr., 81, 635-643.

THIBIER M., 1977. Contribution à l'éfude de la fonction sexuelle chez le jeune faurillon. Thèse Doct. Etat. Univ. P. et M. Curie (Paris VI), 100 pp. 